\title{
PSV Of Basket Circumferentil Artery
}

\author{
Muhammad Anwar* and Syed Amir Gilani \\ University of Lahore, Pakistan
}

Submission: December 12, 2017; Published: April 10, 2018

"Corresponding author: Muhammad Anwar, MBBS MPhil, University of Lahore, Al Badar Medical Complex, Nowshra Virkan, Gujranwala, Pakistan, Email: rubabzohra@gmail.com

\section{Introduction}

Neovascularisation develops around the HCC and malignant tumours of liver in basket form .this leads to increase blood supply via hepatic artery. We have tried to do quantification of hepatic artery, basket vessels and feeding vessels where ever it is found. We have accumulated data of liver tumours (malignanat) from 2013 to September 2017 from our colour Doppler centre. Our centre is located in Punjab province of Pakistan. Here prevalence of hepatitis $\mathrm{C}$ in $6.5 \%$ which is very high [1]. China has the highest burden of HCV infection cases. Pakistan has the second highest burden of HCV positive cases [2]. This is a retrospective study.

\section{Back Ground}

Malignant tumours grow in an uncontrolled fashion with the propensity to spread into the surrounding tissues. Both these critical features are closely dependent from the tumour vascular network $[3,4]$, the development of neo formed vessels is essential for the tumour growth. Tumoural vascularization shows some peculiar biological and morphological features. Firstly, it is not self-limited and tends to grow indefinitely according to the biological behavior of the tumour. Secondly, it develops as a complex, chaotic network at the growing edge of the tumour with irregular and winding branches penetrating the nodule with a radial shape. The number of vessels within the tumour is often, but not always, increased, so that hypervascularity is a common feature. adjacent arteries and veins, mainly at the periphery of the nodule, are frequently observed [10 \pm 12$]$.

Taylor et al. [5] reported that high-velocity Doppler signal was detected in hepatocellular carcinoma tumors when pulsed wave Doppler sonography was used; they suggested that this signal was associated with large pressure gradients due to arteriovenous shunting. In our study, we also observed a fast pulsating blood flow of $70-90 \mathrm{~cm} / \mathrm{sec}$ in maximal velocity in feeding arteries entering the tumor, which form part of the basket pattern [6]. Furthermore, in addition to the pulsating wave, a constant wave could be detected in the periphery in hepatocellular carcinoma. Comparing the blood flows shown on the color image with angiographic findings, we found that the blood flow that creates the basket pattern is the portal vein displaced around mass lesions and feeding arteries surrounding tumor nodules [7]. Also, the blood flow within the tumor displayed by color imaging is the pulsating tumor vessel running within the tumor.

\section{Equipment}

B-scan, colour Doppler and duplex evaluation was done on sonoscape S20 [8]. The insonating frequency of $3-5 \mathrm{~Hz}$ was used for grey scale image \& for colour Doppler frequency of 2.4 was used, PRF of Doppler was 4, increased to 6 a few times to 8 were Doppler alaizing occours (Figure 1).

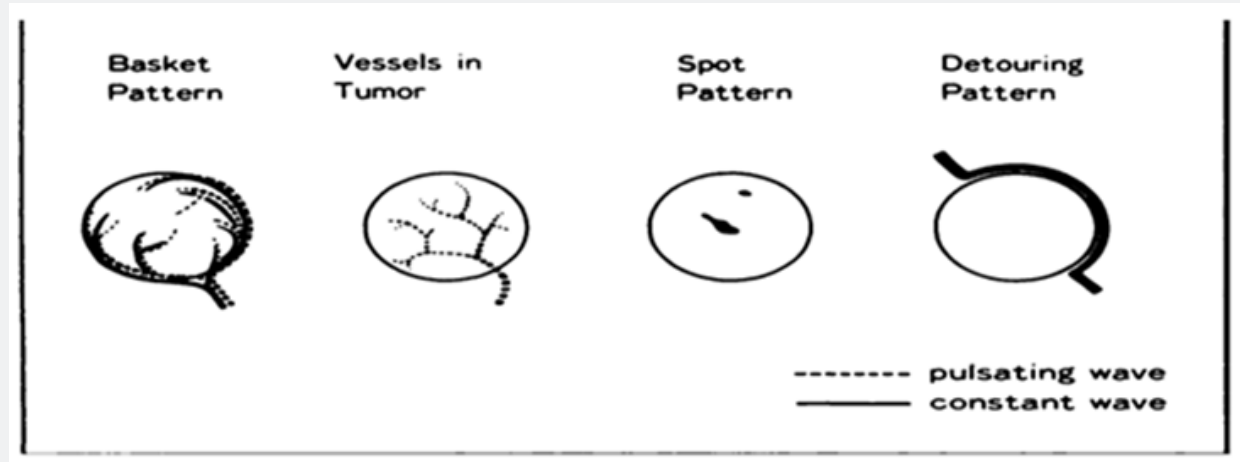

Figure 1: Schematic presentation of blood flow in liver tumours as shown by colour Doppler flow imaging. 
Subject \& Method

Study comprises of 25 patients with almost equal females \& males of age 40 to 70 years Doppler signal of circumferential artery around the mass wherever it was present. In patients with to more than one mass in liver, only the mass with the highest
PSV was considered and analysed with colour and spectral Doppler [9] (Figure 2). Therefore for purpose of data analysis only one lesion was considered. All patients present themselves for ultrasound examination after appointment verbal consent was taken to include in this study.
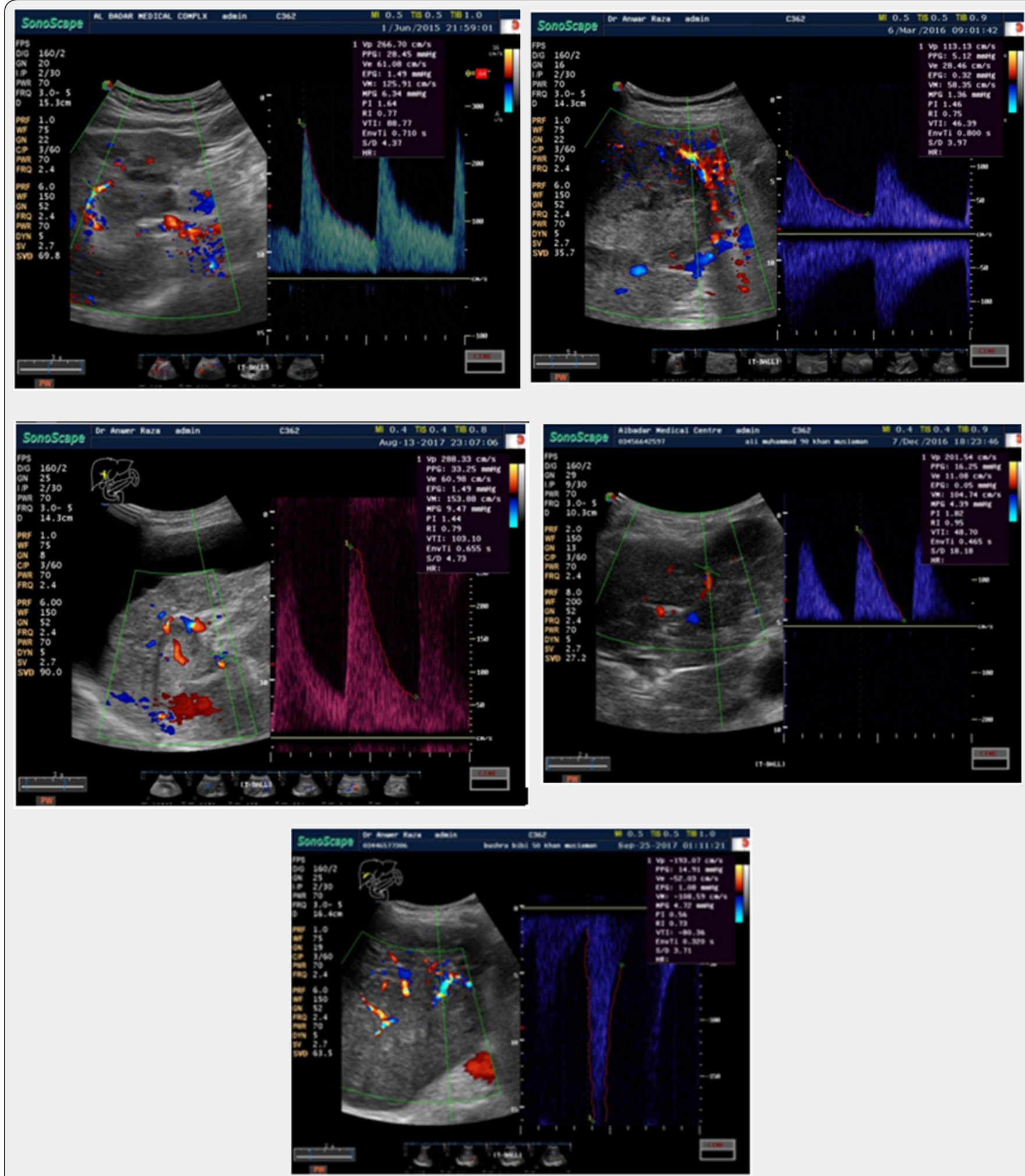

Figure 2: Basket pattern. 


\section{Objective}

It has been studied in past qualitatively but not quantitatively. In this study Quantification is made of PSV of circumferential tumoural arteries (basket vessels) and feeding vessels wherever it is found [10].

\section{Results}

A. Hcc is a specific tumour in which basket pattern vessels or circumferencial vessels around the big HCC show more velocity than hepatic artery and this raise even upto $311 \mathrm{cms}$ / sec. in our study,

B. Average 159 Minimum PSV of basket pattern around HCC $90 \mathrm{cms} / \mathrm{sec}$, maximum being $311 \mathrm{cms} / \mathrm{sec}$.

C. Feeding or penetrating vessels show pulsatile flow and this sometimes $160 \mathrm{cms} / \mathrm{sec}$, minimum $33 \mathrm{cms}$ and average of $83 \mathrm{cms} / \mathrm{sec}$ and this is often below the baseline.

\section{Feeding Ateries}

A. It's open for future researchers to further explore this topic of increased blood supply and its various indices

B. Hcc is a specific tumour in which basket pattern vessels or circumferencial vessels around the big HCC show more velocity than hepatic artery and this rise even upto $235 \mathrm{cms} /$ sec. in our study,

C. Feeding or penetrating vessels show pulsatile flow and this sometimes reach more than basket pattern vessels and this is often below the baseline.
D. It's open for future researchers to further explore this topic of increased blood supply and its various indices.

\section{References}

1. PMRC (2009) Prevalence of hepatitis B\&C in pakistan.

2. Gower E, Estes C, Blach S, Razavi SK, Razavi H (2014) Global epidemiology and genotype distribution of hepatitis $\mathrm{C}$ virus infection. J Hepatol 61(Suppl 1): S45-S57.

3. Abu YMM (1991) Duplex doppler sonography of the hepatic vein in tricuspid regurgitation. AJR Am J Roentgenol 156(1): 79-83.

4. Abu YMM, Milam SG, Farner RM (1990) Pulsatile portal vein flow: a sign of tricuspid regurgitation on duplex Doppler sonography. AJR Am J Roentgenol 155(4): 785-788.

5. Taylor (2009) Current medical imaging review. 5(1).

6. Dietrich CF, Lee JH, Gottschalk R, Herrmann G, Sarrazin C, et al. (1998) Hepatic and portal vein flow pattern in correlation with intrahepatic fat deposition and liver histology in patients with chronic hepatitis C. AJR Am J Roentgenol 171(2): 437-443.

7. Scissons R (2008) Characterizing triphasic, biphasic, and monophasic doppler waveforms. J Diagn Med Sonogr 24(5): 269-276.

8. Joynt LK, Platt JF, Rubin JM, Ellis JH, Bude RO (1995) Hepatic artery resistance before and after standard meal in subjects with diseased and healthy livers. Radiology 196(2): 489-492.

9. Myron AP, MD, University of Wisconstin.

10. Allan PL (1996) Clinical applications of doppler ultrasond. ( $2^{\text {nd }}$ edn). In: KJW Taylor (Ed.), Lippincott-Raven Publishers, USA, 22(4): 527.

\section{Your next submission with JuniperPublishers} will reach you the below assets

- Quality Editorial service

- Swift Peer Review

- Reprints availability

- E-prints Service

- Manuscript Podcast for convenient understanding

- Global attainment for your research

- Manuscript accessibility in different formats

( Pdf, E-pub, Full Text, audio)

- Unceasing customer service

Track the below URL for one-step submission https://juniperpublishers.com/online-submission.php 